\title{
ゾルーゲル法によるアルミナーマグネシア系粉体の作製とその性質
}

\author{
川端浩二 · 山田高明* . 吉松英之 · 尾坂明義** . 三浦嘉也* \\ 岡山県工業技術センター，701-1296 岡山市芳賀 5301 \\ *岡山大学環境理工学部環境物質工学科, 700-8530.岡山市津島中 3-1-1 \\ **岡山大学工学部生物機能工学科, 700-8530 岡山市津島中 3-1-1
}

\section{Preparation and Properties of Alumina-Magnesia Powder by Sol-Gel Method}

\section{Koji KAWABATA, Takaaki YAMADA,* Hideyuki YOSHIMATSU,} Akiyoshi OSAKA** and Yoshinari MIURA*

Industrial Technology Center of Okayama Prefecture, 5301, Haga, Okayama-shi 701-1296

* Department of Environmental Chemistry and Materials, Faculty of Environmental Science and Technology, Okayama University,

3-1-1, Tsushima-Naka, Okayama-shi 700-8530

**Department of Bioscience and Technology, Faculty of Engineering, Okayama University, 3-1-1, Tsushima-Naka, Okayama-shi 700-8530

\begin{abstract}
We examined the effect of raw materials on the properties of alumina-magnesia powders. In particular, we investigated about the amorphous structure of alumina-magnesia powders (AMA20 and AMH20, MgO content $=20 \mathrm{~mol} \%$ ) prepared by sol-gel method. The specific surface area of an AMA20 powder prepared from ethyl acetoacetate aluminum diisopropoxide and magnesium acetate tetrahydrate was larger than that of an AMH20 powder prepared from ethyl acetoacetate aluminum diisopropoxide and magnesium hydroxide. Crystallization behavior and true density depended on the raw materials used for magnesia. It is considered that the alumina and magnesia components in alumina-magnesia amorphous powder AMA20 were homogeneously mixed at the atomic level.

[Received January 25, 2002; Accepted April 18, 2002]
\end{abstract}

Key-words : Sol-gel method, Alumina-magnesia powder, Amorphous, XRD, True density

\section{1. 緒 言}

ゾルーゲル法によるアルミナ系複合粉体の合成において, 種々の原料が複合粉体中の複合成分の均一性に影響を与える場 合がある1),2)。したがって，ゾルーゲル法において，原料と， 得られた粉体中の構成成分の複合化による均性との関連を調 べることは重要である.

アルミナ系複合粉体において，酸性酸化物同士を複合化させ た材料については，例えば，アルミナーシリカ系におけるムラ イト粉体についてなど，今をでに数多くの研究がなされてきて いる，一方，酸性酸化物であるアルミナと塩基性酸化物を複合 化させた複合粉体の研究はあまりなされていない，そこで，本 研究では，アルミナと塩基性酸化物であるマグネシアを複合化 させたアルミナーマグネシア系複合粉体について検討すること とした．アルミナーマグネシア系粉体は，比較的高温で熱処理 することにより結晶化してスピネル構造をとり，構造材料セラ ミックスとして利用されている．しかしながら，比較的低温で 熱処理した場合のアモルファス構造の性質については十分検討 されて抢らず，そのため，その用途も特に定まったものではな い：そこで，本研究では，アルミナーマダネシア系粉体のアモ ルファス構造について調べることを目的に，ゾルーゲル法によ り作製したアルミナーマグネシア系粉体の性質に及ぼす出発原 料の影響について調べた。

\section{2. 実験方法}

アルミナ原料としてエチルアセトアセテートアルミニウムジ イソプロポキシド（川研ファインケミカル製， $\mathrm{ALCH}$ ), マグ ネシア原料として水酸化マグネシウム（岩谷化学工業製, $\mathrm{MH}-30$, 純度 $99.9 \%$, 比表面積 $58.0 \mathrm{~m}^{2} \cdot \mathrm{g}^{-1}$ ) 及び酢酸マグネ シウム四水和物（関東化学製）を用いた．ALCH は，アルミ ニウムトリ-iso-プロポキシドの一つのイソプロポキシ基に代 わってエチルアセトアセテート（アセト酢酸エチル）がキレー
ト化したアルミニウムキレート化合物である。ALCH はエタ ノールに対して溶解性を有しており，酢酸マグネシウム四水和 物は水に対して溶解性を有しているが，水酸化マグネシウムは 水に対して溶解性を有していない。このように，マグネシア 原料として，水に対して溶解性の異なる原料を用いた．組成は $x \mathrm{MgO}-(100-x) \mathrm{Al}_{2} \mathrm{O}_{3}\left(x=\mathrm{MgO} /\left(\mathrm{MgO}+\mathrm{Al}_{2} \mathrm{O}_{3}\right) \times 100(\mathrm{~mol}\right.$ \%)）とし， $x=0 \sim 100 \mathrm{~mol} \%$ の粉体を作製した. 以下に $x=20$ $\mathrm{mol} \%$ の粉体の作製方法を示す． $0.1 \mathrm{~mol}$ の酢酸マグネシウム 四水和物を $15 \mathrm{~mol}$ の水と混合した溶液に, $0.8 \mathrm{~mol}$ の ALCH を $5 \mathrm{~mol}$ のエタノールに溶かした溶液を加えて混合ゲル化さ せ，ゲル（AMA20）を得た．同様の方法により，酢酸マグネ シウム四水和物の代わりに水酸化マグネシウムを用いて，ゲル

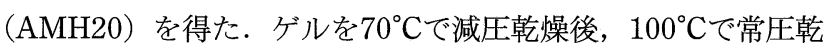
燥して乾燥ゲルを得た。この乾燥ゲルを大気雾囲気下において 昇温速度 $300^{\circ} \mathrm{C} \cdot \mathrm{h}^{-1}$ で $500 \sim 1000^{\circ} \mathrm{C}$ まで昇温後, $2 \mathrm{~h}$ 保持して 焼成を行いアルミナーマグネシア系粉体 AMA20及び AMH20 を得た.

窒素ガス吸着等温線を日本ベル製，BELSORP 28SA を用い て, $77 \mathrm{~K}$ において測定し，BET法により比表面積 $\left(S_{\mathrm{N}_{2}}\right)$, $\mathrm{DH}$ 法により細孔径分布を求めた。 また， $\mathrm{CO}_{2}$ ガス吸着等温線 を，日本ベル製，BELSORP 28SA を用いて，195 K において 測定し， BET 法により比表面積 $\left(\mathrm{S}_{\mathrm{CO}_{2}}\right)$ を求めた. X 線回折 (XRD) 装置（理学電機製，RINT-1300）を用いて，結晶相 の同定を行った. 真密度はユアサアイオニクス製, ウルトラピ クノメーター1000により, He ガス置換法により測定した.

\section{1 比表面積及び細孔径分布}

図 1 に $700^{\circ} \mathrm{C}$ で熱処理したアルミナーマグネシア系粉体 AMA 及び $\mathrm{AMH}$ の組成と比表面積 $\left(S_{\mathrm{N}_{2}}\right)$ の関係を示す. $\mathrm{AMH}$ $\mathrm{MgO}$ 含有量の増加とともに, 比表面積はほぼ単調に減少し 


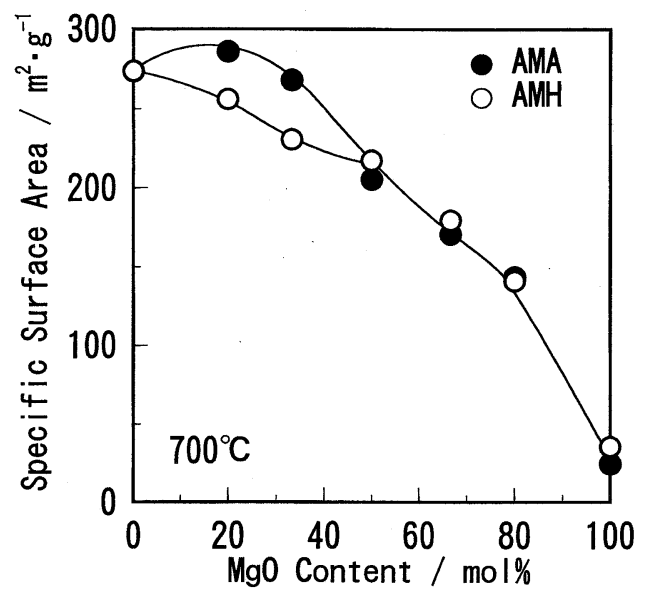

Fig. 1. Specific surface area of AMA and AMH powders as a function of $\mathrm{MgO}$ content.

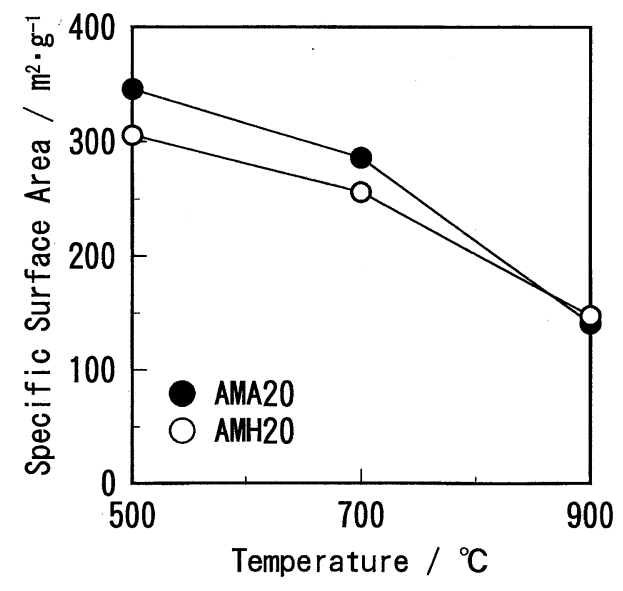

Fig. 2. Change in the specific surface area with heating temperature for AMA20 and AMH20 powders.

た.それに対して，AMAでは， $x=20 \sim 33.3$ mol\%において 比表面積は $268 \sim 286 \mathrm{~m}^{2} \cdot \mathrm{g}^{-1}$ となり, $\mathrm{AMH}$ と比較して高い比 表面積を有し, $x=33.3 \mathrm{~mol} \%$ 以上では, $\mathrm{MgO}$ 含有量の増加と 共に，比表面積は減少した。 図 1 において比表面積に差が生じ ていた $x=20 \mathrm{~mol} \%$ の試料について更に詳しく調べるために, $500 \sim 900^{\circ} \mathrm{C}$ で熱処理した $x=20 \mathrm{~mol} \%$ の AMA20及び AMH20 の比表面積 $\left(S_{\mathrm{N}_{2}}\right)$ を図 2 に示す. AMA20の比表面積は $500^{\circ} \mathrm{C}$ の場合が $346 \mathrm{~m}^{2} \cdot \mathrm{g}^{-1}, 700^{\circ} \mathrm{C}$ 場合が $286 \mathrm{~m}^{2} \cdot \mathrm{g}^{-1}$ となり $900^{\circ} \mathrm{C}$ の場合が $141 \mathrm{~m}^{2} \cdot \mathrm{g}^{-1}$ であった. AMH 20 の比表面積は $500^{\circ} \mathrm{C}$ の 場合が $306 \mathrm{~m}^{2} \cdot \mathrm{g}^{-1}, 700^{\circ} \mathrm{C}$ 場合が $256 \mathrm{~m}^{2} \cdot \mathrm{g}^{-1}$ となり $900^{\circ} \mathrm{C}$ の 場合が $148 \mathrm{~m}^{2} \cdot \mathrm{g}^{-1}$ であった. AMA20及び AMH 20 共に熱処理

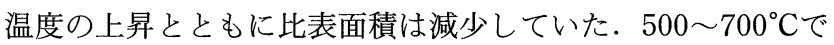
は AMH20 と比較して, AMA20の方が大きい比表面積を有し ていた.

図 3 に $700^{\circ} \mathrm{C} て ゙$ 熱処理した $\mathrm{AMA} 20$ 及び $\mathrm{AMH} 20$ の細孔径分 布を示す. 図 3 より, AMA20及び AMH20共に細孔半径 1 6 $\mathrm{nm}$ 程度のメソ孔を有していた。平均細孔半径は, AMA20は $2.7 \mathrm{~nm}, \mathrm{AMH} 20$ では3.5 nm であり, AMA20の方が小さい細 孔を有していた. 図 1 において AMA20の方が AMH20 と比較 して大きい比表面積を示すのは, AMA20の方が AMH20 と比 較して小さい細孔を有しているためと考えられる. 以上の結果 より, $x=20 \mathrm{~mol} \%$ において, マグネシア原料に水酸化マグネ

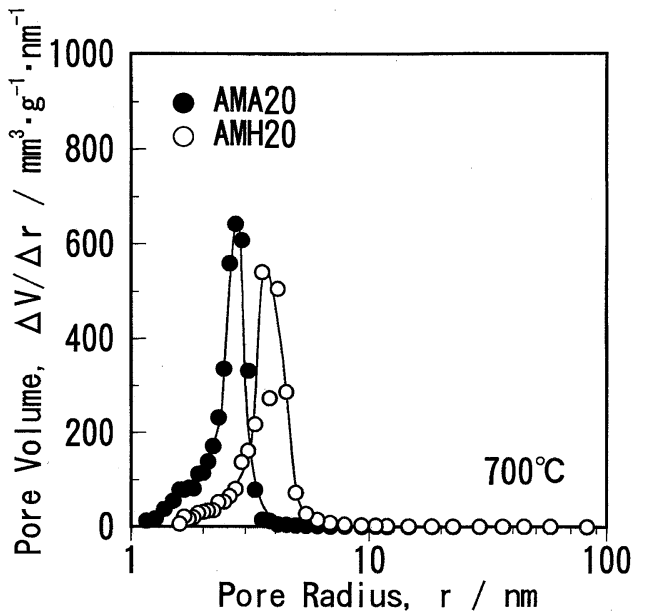

Fig. 3. Pore size distributions of AMA20 and AMH20 powders.

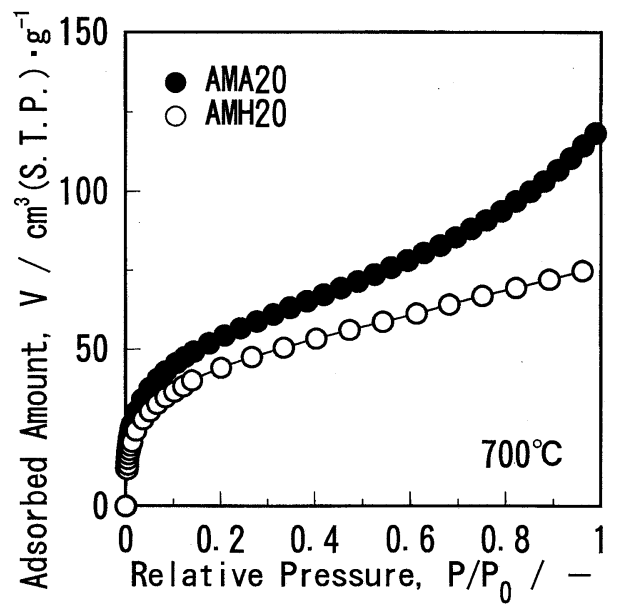

Fig. 4. Adsorption isotherms of $\mathrm{CO}_{2}$ gas at $195 \mathrm{~K}$ on $\mathrm{AMA} 20$ and AMH20 powders.

シウムを用いた場合と比較して，酢酸マグネシウム四水和物を 用いることによって, より細孔が小さく高い比表面積を有する アルミナーマグネシア系粉体が得られた.

図 4 に $700^{\circ} \mathrm{C}$ で熱処理した $\mathrm{AMA} 20$ 及び $\mathrm{AMH} 20$ の $\mathrm{CO}_{2}$ ガス 吸着等温線を示す. AMA20及び AMH20を比較すると $\mathrm{CO}_{2}$ ガ ス吸着量に差が見られ, $\mathrm{AMH} 20$ と比較して, AMA20の方が $\mathrm{CO}_{2}$ ガス吸着量が多い. $\mathrm{CO}_{2}$ ガス吸着等温線から求めた比表 面積 $S_{\mathrm{CO}_{2}}$ は, AMA20は2 $29 \mathrm{~m}^{2} \cdot \mathrm{g}^{-1}, \mathrm{AMH} 20$ では $191 \mathrm{~m}^{2} \cdot \mathrm{g}^{-1}$ となり, をた, $S_{\mathrm{CO}_{2}} / S_{\mathrm{N}_{2}}$ を求めた結果, $\mathrm{AMA} 20$ は 0.80 , AMH20では 0.74 となった。このことから, AMA20の方が $\mathrm{CO}_{2}$ ガスをより多く吸着する性質を有することが分かった。 $\mathrm{CO}_{2}$ ガスは酸性ガスであることから, 塩基性を示す粉体表面 に選択的に吸着すると考えられる．したがって， $x=20 \mathrm{~mol} \%$ においてマグネシア原料に水酸化マグネシウムを用いた場合と 比較して, 酷酸マグネシウム四水和物を用いることにより, 粉 体表面がより塩基的性質を有することが分かった。

\section{$3.2 \mathrm{XRD}$ 及び真密度}

図 5 及び図 6 に AMA20及び AMH20の XRD 測定の結果を 示す. AMA20は500 $600^{\circ} \mathrm{C}$ ま゙は結晶ピークは確認されずア モルファスと思われ， $700 \sim 1000^{\circ} \mathrm{C}$ ではスピネル $\left(\mathrm{MgAl}_{2} \mathrm{O}_{4}\right)$

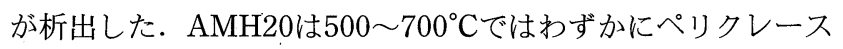




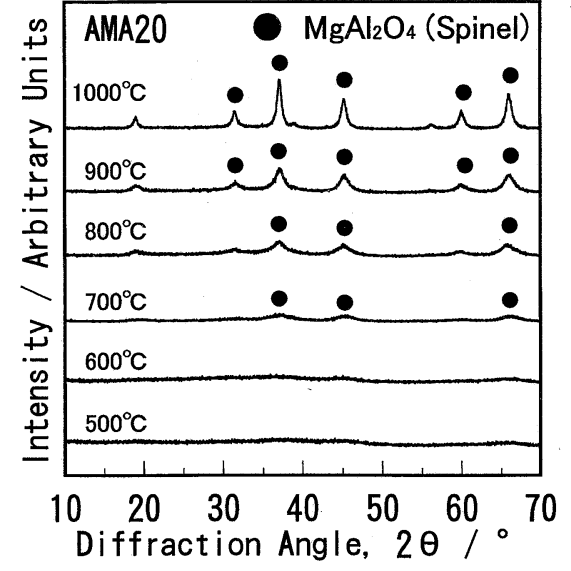

Fig. 5. XRD patterns of AMA20 powders.

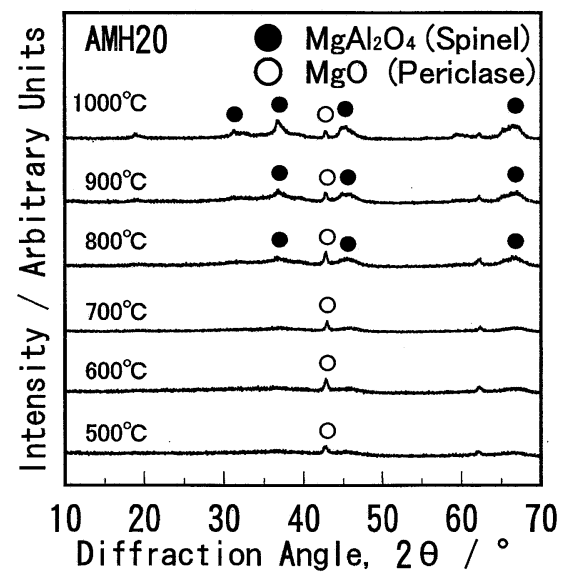

Fig. 6. XRD patterns of AMH20 powders.

（MgO）が析出した. $800 \sim 1000^{\circ} \mathrm{C}$ ではペリクレースに加えス ピネルが析出した. スピネルの結晶析出温度は, AMA20は

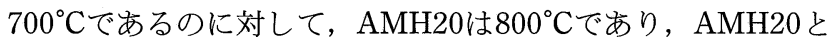
比較して，AMA20の方がより低い温度でスピネルが析出して おり， $700^{\circ} \mathrm{C}$ 以上において結晶構造の違いが確認された。一 方， $600^{\circ} \mathrm{C}$ 以下では $\mathrm{AMA} 20$ はアモルファス, $\mathrm{AMH} 20$ はわず かにペリクレースが析出しているものの大部分がアモルファス でめり, 両者のアモルファス構造の違いについては XRD 測定 からは十分には分からなかった。

図 7 に500 900 ${ }^{\circ} \mathrm{C} て ゙$ 熱処理したアルミナーマグネシア系粉体 AMA20及び AMH20の真密度を示す. AMA20の真密度は $500^{\circ} \mathrm{C}$ では $2.8 \mathrm{~g} \cdot \mathrm{cm}^{-3}, 700^{\circ} \mathrm{C}$ では $3.0 \mathrm{~g} \cdot \mathrm{cm}^{-3}, 900^{\circ} \mathrm{C}$ では $3.2 \mathrm{~g} \cdot \mathrm{cm}^{-3}$ となった. $\mathrm{AMH} 20$ の真密度は $500^{\circ} \mathrm{C}$ で $3.0 \mathrm{~g} \cdot \mathrm{cm}^{-3}, 700^{\circ} \mathrm{C} て ゙$

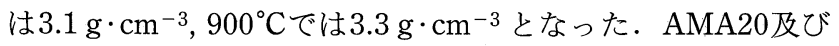
AMH20の真密度は熱処理温度の上昇とともに大きくなった. また, いずれの温度でも, AMA20の真密度は AMH20 と比較 して小さくなった. 真密度は $\mathrm{He}$ ガス置換法により測定してい るため, 細孔の影響をほとんど受けることなく, 酸化物自身の 密度を表しており, 真密度は酸化物構造に依存している值であ る. AMA20 と AMH20は同じ組成であるので, 真密度の違い はAMA20 とAMH20の酸化物構造が異なっていることを示唆 している. アモルファスの真密度は, 原子の充填状態に依存し ており, ランダム性が高い原子配列では真密度が小さく, 最密

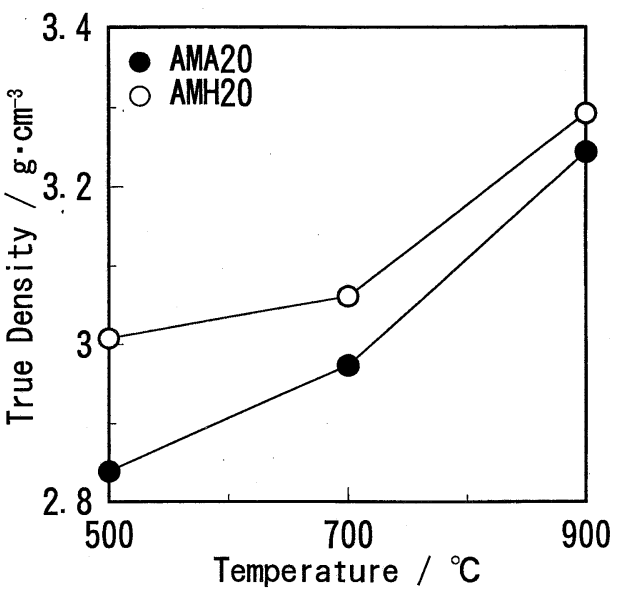

Fig. 7. Change in the true density with heating temperature for AMA20 and AMH20 powders.

充填状態の原子配列に近づくに従い真密度は大きくなる2). 図 7 で温度の上昇に伴い, 真密度が大きくなったのは, 原子 がより最密充填（結晶化）する方向に再配列しているためでめ ると思われる. AMA20の真密度が AMH20 と比較して小さい ことは，AMA20の方が AMH20より原子の配列のランダム性 が高いことを示唆している．この理由として，AMA200方が アルミナ成分とマグネシア成分の複合化による均一性が向上し ているためと推察できる．以上のように，XRD 及び真密度の 結果から， AMH20 と比較してAMA20の方がアルミナ成分と マグネシア成分がより原子レベルで複合化していることが推察 された。これは，AMA20乾燥ゲルは，ALCH が酢酸マグネシ ウム四水和物水溶液によりゲル化することで, $\mathrm{Al}$ と $\mathrm{Mg}$ が原 子レベルで複合化しているためではないかと考えている。一 方, AMH20乾燥ゲルは, ALCH と水酸化マグネシウムの混合 により，水酸化マグネシウム粒子の周りに ALCH のゲル化に より生成したアルミナゲルが存在しており， $\mathrm{Al}$ と $\mathrm{Mg}$ の原子 レベルでの複合化反応があまり進行していない状態ではないか と考えている.このように，AMA20は乾燥ゲルの状態で $\mathrm{A} 1$ と Mg が原子レベルで複合化しているため, 熱処理後につい てもAMA20は AMH20よりもアルミナ成分とマグネシア成分 がより均一に複合化していると考えられる.

\section{4. まとめ}

ゾルーゲル法により作製したアルミナーマグネシア系粉体の 性質に及ぼす出発原料の影響について調べた。その結果, AMA20の比表面積は AMH20 と比較して大きくなった．ま た，AMA20は AMH20 と比較して粉体表面がより塩基的性質 を示していた．結晶析出温度及び真密度の違いから，AMA20 と AMH20ではアモルファス構造が異なっており，AMA20の 方がアルミナ成分とマグネシア成分がより均一に複合化してい るものと示唆された.

\section{文献}

1) Kawabata, K., Yoshimatsu, H., Yabuki, T., Osaka A. and Miura, Y., J. Ceram. Soc. Japan, 104, 458-61 (1996) [in Japanese].

2) Kawabata, K., Yoshimatsu, H., Yabuki, T., Kubotsu, A., Hayakawa, S., Osaka, A. and Miura, Y., J. Ceram. Soc. Japan, 106, 155-59 (1998) [in Japanese]. 